\title{
Human Rights: temporarily out of order. Narrative and practice during pandemic times
}

\begin{abstract}
Human Rights: temporarily out of order. Narrative and practice during pandemic times
\section{Abstract}

What is the origin of the narrative of human rights? What interests do they represent? Can human rights help reverse the devastating consequences of the COVID-19 pandemic on impoverished children? To answer this question, we will discuss the origin of the narrative and discourse of human rights and their potential as enforcement mechanisms for reversing vulnerability, preventing abuses and promoting solidarity and justice. Despite their promise, the past decade has seen a backlash against human rights on almost every front, worsened by the coronavirus outbreak which is causing a widespread global disruption and exacerbating pre-existing inequalities. We consider the impact on vulnerable children in Latin America, which has greatly worsened since the spread of coronavirus. Finally, we discuss the impact of pandemic on children's rights, as well as initiatives relating to increasing their level of protection and guaranteeing to the exercise of their rights, which have been severely compromised during these turbulent times.
\end{abstract}

\section{Keywords}

Human Rights - COVID-19 - Children's rights - Latin America

\section{Introduction}

The tradition of the oppressed teaches us that the 'state of emergency' in which we live is not to exception but the rule

Walter Benjamin

Human rights are part of a cognitive perspective that is, by its nature and origin, Eurocentric. Since the beginning of modernity, this perspective was imposed and 
accepted throughout the capitalist world as the only possible mode of rationality, transcending the geographical scope of Europe to reach the colonial world. However, we argue that the origin of the discourse and narrative of human rights should not discredit their potential for change in peripheral regions of the world. Just as world superpowers have used the ideology of human rights to rationalize and justify their domination, human rights can also encourage resistance - not based on a formal or legalistic interpretation, but a creative resistance that enables the mobilization of marginal, subaltern narratives, with special focus in the semi-peripheral situation of Latin America.

At a time of widespread conflicts, injustice, poverty and violence, we must resort to whatever instruments promote higher standards of living. In this sense we highlight the potential of human rights as an enforcement mechanism to help create a dignified life for the millions of persons who struggle for survival and recognition. But the past decade has seen a backlash against human rights on almost every front and, most recently, the coronavirus outbreak has disrupted the global economy and exacerbated pre-existing inequalities. Finally, we discuss the negative impact of pandemic on children, which require increasing their level of protection and guarantee access to their rights, severely compromised during these turbulent times.

\section{The multiple uses of Human Rights}

Human rights are part of a cognitive perspective that is, by its nature and origin, Eurocentric. Since the beginnings of modernity, this perspective was imposed and accepted as the only possible mode of rationality, transcending the geographical scope of Europe to reach the colonial world. Among other consequences, it produced the naturalization of experiences, identities and historical relationships of coloniality and of the geocultural distribution of world capitalist power. ${ }^{1}$ The hegemony of Eurocentric thought remains today and constitutes a widespread perspective in Latin America, perhaps due to the fact that "Eurocentrism is not the cognitive perspective of Europeans exclusively, or only of the dominators of world capitalism, but of those educated under its hegemony".

This raises a need for reflection on the cultural and political context of human rights production in order to discuss the presumed universality of knowledge that seeks to suppress alternative/traditional understandings of the world. This "epistemicide" that seeks the homogenization of the world was functional to the colo-

\footnotetext{
1 A. Quijano, Antología Esencial, Buenos Aires 2014.

2 Ibidem, 69.
} 
nizing mission and was possible thanks to the political, economic and military interventions of modern colonialism and capitalism. ${ }^{3}$ Another significant discussion addresses the two opposing ideological views at the origin of the debates on human rights. One of them suggests that human rights are concessions or privileges granted to people as individuals, while the other emphasizes their social aspect and sees society as traversed by struggles and conflicts of a historical, constructed nature. ${ }^{4}$ The dichotomy between the basis for human rights being individual or collective has significant practical consequences; while central countries would have given priority to individual rights over collective rights, in the peripheral countries the opposite trend has been observed.

These tensions were also present in the East-West debate from when the Convention on the Rights of the Child was being outlined: on the one hand, the countries that made up the Soviet bloc were fighting for the primacy of social rights, while the United States opposed it, arguing that "social rights do not exist", since there is nothing that can be demanded that cannot be ultimately attributed to an individual. In this regard, the UN considers human rights to be complementary and mutually reinforcing: "sometimes the value and dignity of persons can only be ensured through the recognition and protection of individual rights as members of a group".

\section{The double standard of human rights}

The human rights narrative acquired its current form during the second post-war period, at which time it reflected the political and ideological confrontations underlying the Cold War, a war that was actually "very hot" in the countries of the so-called Third World and especially in Africa. During this period and still today, the United States presented themselves as the guarantors of democracy, liberty, and individual rights, while at the same time promoting or supporting dictatorships in Africa, Asia and Latin America.

The political rhetoric of the United States, now as much as at that time, has tended towards the concealment its imperialist role under the democratic cloak of human rights. But Amnesty International mentions that all over the world, on any given day, a man, woman or child is likely to be displaced, tortured, murdered or disappeared at the hands of governments or political armed groups; very often,

\footnotetext{
${ }^{3}$ B. de Sousa Santos, M.P. Meneses (eds.), Epistemologías del Sur: Perspectivas, Madrid 2014.

${ }^{4}$ I.G. Shivji, The Struggle for Democracy, Tanzania 2003.

${ }^{5}$ United Nations High Commissioner for Refugees [UNHCR], Global Trends: Forced Displacement in 2019, Geneva 2020.

${ }^{6}$ A. Quijano, op. cit.
} 
the United States shares this responsibility. The double standard of human rights is an ideological operation that conceals the true objective of military interventions in peripheral but strategic regions of the world. It is applied by the United States and other powers that carry out actions that impose their interests even if this implies violating the well-being, autonomy, material and symbolic resources of other regions and their populations, relying on the legitimacy conferred by claiming to act on the behalf of human rights. This double standard is not easily perceived, however, because human rights are usually presented as ahistorical, apolitical and asocial values, "inherent to every human being".

\section{The performativity of human rights}

Hannah Arent argues that despite being conceived as belonging to all humanity, human rights have only had meaning within sovereign zones from the very moment of their enunciation. For this reason, refugees and stateless persons represent "the very end of human rights", expelled not only from their communities but also from humanity-what she calls "human rightlessness". In other words, the people who most need the guarantee and protection of human rights are those to whom these rights are denied; since they are attributed only to persons who were already considered citizens. Nevertheless, human rights law is the consequence of a power struggle to give visibility to certain demands; as Segato states: "the text of the law is the master narrative of a nation and from this derives the struggle to obtain legitimacy and audibility within that narrative; these are real and important symbolic struggles". That is to say, the law is the consequence of the symbolic struggle to give legitimacy to certain demands to the detriment of others in the field of power. Again, Segato writes: "despite having its origin in an act of force with which the dominant ethnic group imposes its code on dominated ethnic groups, law thus imposed begins to behave, from the moment of its promulgation, as an arena of multiple disputes and tense interlocutions".

Bourdieu mentions that law confers the status of reality to the social groups whose rights it guarantees, instituting their existence with the "mere act of nomination" ${ }^{10}$ The power of the nomination transcends the linguistic level to become an operation with real practical consequences. That is why human rights treaties are considered "performative acts of speech" that give entity to what they

${ }^{7}$ H. Arendt, The Human Condition, Chicago 1958.

${ }_{8}$ R.L. Segato, Antropologia e direitos humanos: alteridade e ética no movimiento de expansão dos direitos universais, "Mana" 2006, 12(1).

${ }^{9}$ Ibidem.

${ }^{10}$ P. Bourdieu, O Poder Simbólico, Brasil 1989. 
represent: "the state of affairs represented in the propositional content of acts of speech acquires existence by the same performativity of the act of speech". ${ }^{11}$ In this sense, the great advance of human rights and the rights of the child in postcolonial contexts consists of the "mere act" of naming certain phenomena through which they are given entity. Baxi mentions the impossibility of naming human rights violations in the absence of human rights norms and standards. However, the current proliferation of discourses, actors, agencies, portals, platforms, and other anonymous and massive productions of discourse on human rights may lead to a point where the production of human rights is everyone's business in general, but no one's in particular. The "dense intertextuality" of the enunciation of human rights does not always manage to register and account for the aspirations and concrete struggles of people situated in time and space. For this reason, Baxi tries to identify what aspirations human rights represent and what strategic interests they serve, which leads to the distinction between the text and its interpretation, as well as to the consideration of intertextuality since no text - no narrative - is produced outside of society or of history. One of the problems in this regard has to do with the translation of human rights and their narratives. In this sense, discursive, historical and postcolonial perspectives can help us recognize the political and ideological implications of these treaties. Related is the notion of subaltern cosmopolitanism, coined by Santos, which refers to "putting the focus of attention on those who live in misery in a world of abundance" and realizing that understanding of the world greatly exceeds the western understanding of the world. Santos considers that political resistance alone is not enough and that an "epistemological resistance" is also necessary, since this task requires alternative thinking. In this sense, he demands this cosmopolitanism for anyone who is a victim of intolerance and discrimination; anyone whose basic dignity is denied needs a community of human beings. This proposal can be extended to the field of human rights: "many times they [human rights] were, and continue to be, appropriated by subaltern and oppressed social groups to legitimize their causes and strengthen their struggles"12, that is to say that human rights as a symbolic device can be capitalized by both hegemonic and marginal narratives, and in the latter case, contribute to recreate democracy.

In Latin America, the current relevance of the issue of human rights finds its origins in the 1970s due to the proliferation of dictatorships that systematically violated these rights at that time. These events made clear the potential of human rights for political action (other than party politics) and for social change. But because of this, the aforementioned difficulties must be considered and overcome.

\footnotetext{
11 U. Baxi, The future of Human Rights, Oxford 2002.

12 B. Santos, M.P. Meneses, op. cit.
} 
Amongst them; the epistemicide does not consider the conditions of the context of application, the double standard as a criterion for recognition and differential application, and the material conditions of life that entail reproduction poverty and vulnerability in the region. That is why it is necessary to carry out a creative interpretation of human rights that enables the conditions for the appropriation of rights and the mobilization of marginal narratives based on the specificity of Latin American societies.

\section{The backlash against human rights}

The backlash against human rights can take many forms, but, though it is not a unified concept, it can be understood to be a strong negative reaction by a state against international human rights law and/or its promoters. ${ }^{13}$ Those reactions might include the targeting of actors, organizations, minorities, the rejection of a law, etc. - something that can happen in dictatorships but also in democratic regimes with nationalist, authoritarian, populist leaders such as those in Russia, Hungary, Poland, Turkey and many others.

The human rights narrative can be considered one of the greatest moral accomplishments of western civilization. But even though each of the six major human rights treaties has been ratified by more than 150 countries, many of those states remain hostile to human rights. This raises the nagging question of how much human rights law has actually influenced the behavior of governments. ${ }^{14}$ The past decade has seen a backlash against human rights in almost every front; including the rights of woman, minorities, migrants, refugees, informal workers and other vulnerable groups, as well as a regression on environmental rights. Many analysts agree that September 11, 2001 changed the situation. Human rights were set back as a number of countries decided that fighting terrorism was the greatest security challenge. This may have seemed "reasonable" but, in the process, many of them committed appalling violations of human rights in the name of counterterrorism. Another problem arises when state interventions appeal to human rights, since they offer an array of narratives, for instance, that justify organized (state) violence. In the international context, the doctrine of "just war", "humanitarian intervention," and more recently the "responsibility to protect" are prominent features in this vein. 2019.

${ }^{13}$ S. Dragić, On the Concept of the 'Human Rights Backlash', "Imagining the Human", Vienna

${ }^{14}$ E. Posner, The Case against Human Rights, https://www.theguardian.com/news/2014/ dec/04/-sp-case-against-human-rights [accessed: 20.05.2021]. 
Some of the scenarios in which the backlash against human rights can be identified are mention by the UN Assistant Secretary General for Human Rights ${ }^{15}$ : in Brazil, one of the largest democracies in the world, every year more than a thousand people are killed by the police. The prohibition of extrajudicial killings is central to human rights law, a tenet that is flagrantly violated in Brazil. This is also commonplace in countries such as India (the world's largest democracy), South Africa, the Dominican Republic and Iran. According to Gilmour, the courts are slow and underfunded so police, under pressure to combat crime, employ extrajudicial methods - such as torture - to extract confessions.

Other facts that reflect this backlash are: the proliferation of detention centers along the United States' southern border, where mostly Central American migrants are being held, with children separated from their families; the application of laws designed to restrict the funding and activities of nongovernmental organizations, especially human rights NGOs; the attacks on LGBTI issues and women's sexual and reproductive rights; the suppression of rights of immigrants and ethnic and religious minorities and the withdrawal of states from human rights institutions and conventions and, in much of the Islamic world, women lack equality, religious dissenters are persecuted and political freedoms are curtailed. This backlash can also be identified in the normalization of long-lasting armed conflicts with no peaceful solution in sight (Syria, Afghanistan, Yemen, Ethiopia, Sudan, Somalia, Libya, Mali, and Maghreb, amongst others).

The estimations of human slavery alone clearly show that something has gone wrong with human rights. According to the International Labour Organization an estimated 40.3 million people are in modern slavery, including 24.9 million in forced labor and 15.4 million in forced marriage. This means that out of every 1000 people in the world, 5.4 of them live in modern slavery; additionally, 1 in 4 victims are children. ${ }^{16}$

\section{Impact of COVID-19 in the situation of childhood}

The backlash of the last few years against human rights has been worsened by the coronavirus outbreak which has severely disrupted the global economy and poses enormous health, educational, environmental and social challenges to governments and populations around the world. The COVID-19 pandemic has been con-

15 A. Gilmour, The Global Backlash Against Human Rights, https://www.ohchr.org/EN/NewsEvents/Pages/DisplayNews.aspx?NewsID=23202\&LangID=E [accessed: 27.05.2021].

${ }_{16}$ International Labour Organization [ILO], Global Estimates of Modern Slavery: Forced Labour and Forced Marriage, Geneva 2017. 
sidered "the most crucial global health calamity of the century"17 and "the greatest challenge that humankind has faced since the Second World War". ${ }^{18}$ It has been especially devastating for children and their rights, especially after the lockdown and confinement measures, and for children in situation of vulnerability. While children who contract COVID-19 seem to have fewer symptoms and mortality rates than other groups, there are several immediate socio-economic impacts that directly affect children and risks for the protections of children that are emerging daily due to the measures taken to prevent and contain the virus. ${ }^{19}{ }^{T}$ The $\mathrm{OHCHR}{ }^{20}$ states that lockdowns and confinement measures have severe effects on children's rights to health (both mental and psychical), as well as on their rights to education, to play, to a family environment and to be free from violence, amongst others. They also point out that children may be confined in homes that are overcrowded or do not meet adequate standards of living.

Education is one of the elements of society that was most drastically reshaped by the coronavirus pandemic and the closure of schools all over the world. According to UNESCO ${ }^{21} 90 \%$ of the world's student population was affected by school closures. Schools have been completely closed for almost an entire year for more than 168 million children globally. ${ }^{22}$ This crisis has exposed the disparities in countries' emergency preparedness, internet access and availability of learning materials. Many public schools were not set up to implement virtual lessons because they did not have the technology or the equipment to provide online teaching. While children aged 13 and older may already be familiar with social media, the pandemic has introduced younger children to social networking tools that may not be designed for them and for which they may have limited preparation. ${ }^{23}$

A problem that may be hard to ascertain is that, according to the United Nations, half of the world has no internet access. Even for the other half, there are other difficulties, one of them being the oversized influence of big tech companies

17 World Health Organization [WHO], Coronavirus Disease (COVID-19) Pandemic, 2020, https://www.who.int/emergencies/diseases/novel-coronavirus-2019 [accessed: 17.06.2021].

18 United Nations [UN], COVID-19 Response, 2021, https://www.un.org/en/coronavirus/unsecretary-general [accessed: 02.06.2021].

19 Human Rights Watch [HRW], COVID-19's Devastating Impact on Children, https://www. hrw.org/news/2020/04/09/covid-19s-devastating-impact-children [accessed: 15.05.2021].

20 UN High Commissioner for Human Rights [OHCHR], Annual Report 2020: Human Rights at the Heart of COVID-19 Response and Recovery, https://www.ohchr.org/EN/News Events/Pages/ Annual-Report-2020.aspx [accessed: 12.05.2021].

21 UNESCO, Educational Disruption and Response, https://en.unesco.org/covid19/educationresponse [accessed: 14.06.2021].

22 UNICEF, The Impact of COVID-19 on Children's Access to Justice?, United Nations Children's Fund, Division of Data, Analytics, Planning and Monitoring, 2021.

23 UNICEF, op. cit. 
in shaping education policy and how little information they provided as to how they are processing the data of children. The debate on children's digital rights is in its infancy so most governments still have not passed data protection law for children, nor have many schools included privacy clauses in contracts with Ed Tech providers. ${ }^{24}$ The COVID-19 pandemic has also heightened the risk of sexual exploitation of children online. Spending more time online may increase the likelihood that children come into contact with online predators ${ }^{25}$ and Europol has reported than there has been an increased online activity by those seeking child abuse materials, as a result of COVID-19. Finally, child abuse is less likely to be detected during the COVID-19 crisis, as child protection agencies have reduced monitoring to avoid spreading the virus, and teachers are less able to detect signs of ill treatment with schools closed. ${ }^{26}$

The situation is especially delicate for children in vulnerable situations such as those on the move, in conflict zones, in detention, or street children that may not have access to an adequate standard of living, including housing, food, water, sanitation and hygiene. Millions of children are detained in the justice system, but also millions live in overcrowded camps as refugees, migrants or internally displaced children. Here the impossibility to implement basic measures, like social distancing or frequent hand washing, may facilitate the spread of COVID-19. But also, there's evidence of a reduction of immunizations and treatment for other diseases, which has shown a dramatic increase in deaths from malaria, HIV/AIDS, and tuberculosis. Another problem is that the widespread job and income loss has increased rates of child labor, sexual exploitation and child marriage. According to HRW more than 80 million jobs were lost in 2020, but the pandemic also led to a huge reduction in working hours and pushed millions into "working poverty". Women and young people have been disproportionately hit and it could take years to return to full employment for those who exited the labor market during last year. In this report, HRW also warns that, as the global death toll from COVID-19 increases, a large number of children will be orphaned and vulnerable to exploitation and abuse.

According to the World Health Organization, as for September 2021, there have been more than 218 million confirmed cases of COVID-19 - including 4.5 million deaths - which has already left many children without one or both parents or other caregivers. And orphaned children will be particularly vulnerable to diverse forms of exploitation, including trafficking, sexual exploitation and forced labor. This is a tragic reversal of the progress of rights of child have made in the past few years despite the downward trend in human rights more generally.

\footnotetext{
${ }^{24}$ HRW, op. cit.

25 UNICEF, op. cit.

${ }^{26}$ HRW, op. cit.
} 
In contexts of poverty where children were already struggling with adversity, boys and girls who cannot continue with their education become potential victims of child labor and trafficking for exploitation purposes. This is a widespread reality in peripheral countries where millions of boys and girls are forced to work to contribute to the subsistence of their family or to guarantee their own. In Latin America and the Caribbean at least 140 million people work in informality, which represents around 50\% of laborers. Poverty and extreme poverty in Latin America reached levels in 2020 that had not been observed in the last twenty years (more than 200 million people are poor in the region) as well as a worsening of inequality, employment rates and labor participation, especially for women, due to COVID-19 and despite the emergency social protection measures those countries have adopted to stop it. ${ }^{27}$

It may seem a little ironic that it was last year, 2020, when the ILO Child Labour Convention on the Worst Forms of Child Labor (Convention No. 182 ${ }^{28}$ ) achieved its universal ratification. Not only this, also, for the first time in the ILO's history, an International Labor Convention has been ratified by all 187 member States. Also, the Convention is the most rapidly ratified convention in the history of the organization, since its adoption 21 years ago by the International Labour Conference. Even more ironic may seem the fact that 2021 has been designated as the International Year for the Elimination of Child Labour by United Nations member States. ${ }^{29}$

\section{How human rights narrative could be made operative}

Understanding the conflictive origin of the discourse on human rights constitutes a preliminary step for their reconceptualization as instruments of recognition that make them operative in the peripheral societies of the world system. Shivji pro-

${ }^{27}$ ECLAC/ILO, Coyuntura Laboral en América Latina y el Caribe. El trabajo en tiempos de pandemia: desafíos frente a la enfermedad por coronavirus (COVID-19), https://www.cepal.org/es/publicaciones/45557-coyuntura-laboral-america-latina-caribe-trabajo-tiempos-pandemia-desafios-frente [accessed: 08.05.2021].

${ }^{28}$ It states: "Each Member which ratifies this Convention shall take immediate and effective measures to secure the prohibition and elimination of the worst forms of child labour as a matter of urgency", including: all forms of slavery or practices similar to slavery, such as the sale and trafficking of children, debt bondage and serfdom and forced or compulsory labour, including forced or compulsory recruitment of children for use in armed conflict; the use, procuring or offering of a child for prostitution, for the production of pornography or for pornographic performances; for the production and trafficking of drugs and the work which, by its nature or the circumstances in which it is carried out, is likely to harm the health, safety or morals of children.

${ }_{29}$ Also International Year of Peace and Trust, Creative Economy for Sustainable Development and International Year of Fruits and Vegetables. 
vides many examples of creative uses of human rights, one of them concerning the "right to life", which in mainstream interpretations has been used as the basis of campaigns against the death penalty and torture. But in the poorest countries, lawyers and activists have extended the right to life to shelter, shelter, food and land, since no person can live without the means of subsistence. Upendra Baxi ${ }^{30}$ points out that it is about the "right to be human". As Shivji ${ }^{31}$ argues; just as the dominant interests have used the ideology of human rights to rationalize and justify their domination, the forces that seek to resist to that domination can - and should use human rights to mobilize their resistance.

The origin of the discourse and narrative of human rights should not lead to underestimate the need or possibility of its implementation in the context of Latin American societies. Not based on a formalistic or "legalistic" interpretation, but a creative, "counter-hegemonic" one that contributes to the recreating the specificity of territorial anchoring without renouncing the basic postulates of human rights treaties.

Regarding the aforementioned origin and Eurocentric nature of these treaties, we must consider that the Universal Declaration of Human Rights was adopted in 1948 when the world was emerging from one of the bloodiest war conflicts in history. At that time, rights were still far from "universal", with two-thirds of the world's population living in colonized countries and having been termed "natives". Additionally, the rights presented a clearly individual cut, for example: freedom of expression, freedom to "worship God" in a way that each one considered convenient, among others. They did not address issues such as freedom from colonial oppression or the right to self-determination.

Therefore, to account for the impact that the Convention and human rights in general can have on the lives of children, we must reflect on the origin of their narratives. Historically there have been (at least) two childhoods: one with a guarantee of inclusion in traditional socialization mechanisms and an excluded childhood, in which children do not have, in practice, their rights guaranteed. This - apparent - paradox leads us to reflect on the "double standard" of human rights, which implies a differential recognition according to the socioeconomic belonging of individuals. The discourse of human rights cannot be dissociated from the social and economic context in which the inequities that affect childhood take place, just as the negative effects of the capitalist system cannot be mitigated through partial social regulation since, as Samir Amin mentions and, before him, Polanyi and Karl Marx; "economic values are embedded in social reality".

${ }^{30}$ U. Baxi, Human Rights in a Posthuman World: Critical Essay, Oxford 2007.
31 I.G. Shivji, op. cit. 


\section{Discussion}

The human rights narrative in general and the rights of the child more specifically can help place the effects of inequality on the most vulnerable sectors of the population onto the political and social agenda and translate into institutional actions and programs that work in favor of childhood welfare. This creative and counter-hegemonic reading implies taking them out of the realm of the universal and ahistorical and placing them, as Pilotti ${ }^{32}$ suggests, in a historical and contingent social structure. In this way we avoid the formalism in which rights are presented isolated from context, thereby preventing their appropriation as a historical product result of power struggles for the imposition of a meaning. On the other hand, the importance of linking legal order to historical, economic and social circumstances is argued by Pilotti since the ratification of the Convention on the Rights of the Child in Latin America throughout the decade 1990 can be considered, in the words of Bourdieu ${ }^{33}$, to be "the circulation of a text without its context". However, the implementations of human rights treaties demand overcoming the resistance product of the cultural specificities of the context and the ideological struggles for the imposition of a meaning of childhood.

Finally, it could be argued that human rights law has failed to accomplish its objectives, since there is little evidence that human rights treaties, on the whole, have improved the wellbeing of people. ${ }^{34}$ Moreover, at a time of widespread conflict, injustice, poverty and violence, we must resort to whatever instruments promote higher standards of living. In this sense we highlight the potential of human rights as enforcement mechanisms to help achieve a life of dignity for the millions of people who struggle for survival and for recognition. This potential can be identified in multiple initiatives, especially those involving younger generations; amongst them:

- Global activism, especially digital activism since social media has become the key site where protest identities are created, channeled, and contested, making digital platforms critical for understanding the emergence and persistence of protest movements ${ }^{35}$;

- Young people and youth-led protest movements which have embraced digital technologies to campaign and raise awareness on climate change, racial

${ }^{32}$ F. Pilotti, Globalización y convención sobre los Derechos del Niño: el contexto del texto, Washington 2000.

${ }^{33}$ P. Bourdieu, op. cit.

${ }^{34}$ E. Posner, op. cit.

${ }^{35}$ P. Gerbaudo, E. Treré, In Search of the 'We' of Social Media Activism: Introduction to the Special Issue on Social Media and Protest Identities, "Information, Communication \& Society" 2015, 18(8), 865-871. 
injustice, voting rights and other surfacing inequalities, using digital platforms and redefining civic engagement ${ }^{36}$;

- Women's movements that are shaping policies, practices, and conversations; pursuing crucial efforts to preserve or advance human rights, despite huge and often violent opposition.

Currently, across multiple issues, young people are becoming active participants in driving dialogues with policy-makers, empowering the citizens of the communities in which they reside, taking an active role in shaping the future, as they demand awareness but also change. From climate to health to politics, young people are the most affected and they are building upon existing issues and movements, creating new alliances and driving conversations and action. ${ }^{37}$ In this sense, it is clear that new generations are relying on values and ideas deeply rooted in the human rights narratives to change the status quo and finding ways to enact change for a better future.

\section{Bibliography}

Arendt H., The Human Condition, Chicago 1958.

Baxi U., Human Rights in a Posthuman World: Critical Essay, Oxford 2007.

Baxi U., The Future of Human Rights, Oxford 2002.

Bourdieu P., O Poder Simbólico, Brasil 1989.

de Sousa Santos B., Meneses M.P. (eds.) Epistemologías del Sur: Perspectivas, Madrid 2014.

Dragić S., On the Concept of the 'Human Rights Backlash', "Imagining the Human", Vienna 2019.

ECLAC/ILO, Coyuntura Laboral en América Latina y el Caribe. El trabajo en tiempos de pandemia: desafíos frente a la enfermedad por coronavirus (COVID-19), https://www.cepal.org/es/publicaciones/45557-coyuntura-laboral-america-latina-caribe-trabajo-tiempos-pandemia-desafios-frente [accessed: 08.05.2021].

Gerbaudo P., Treré E., In Search of the 'We' of Social Media Activism: Introduction to the Special Issue on Social Media and Protest Identities, "Information, Communication \& Society" 2015, 18(8), 865-871.

Gilmour A., The Global Backlash Against Human Rights, https://www.ohchr.org/EN/NewsEvents/ Pages/DisplayNews.aspx?NewsID=23202\&LangID=E [accessed: 27.05.2021].

Human Rights Watch [HRW], COVID-19's Devastating Impact on Children, https://www.hrw.org/ news/2020/04/09/covid-19s-devastating-impact-children [accessed: 15.05.2021].

International Labour Organization [ILO], Global Estimates of Modern Slavery: Forced Labour and Forced Marriage, Geneva 2017.

Jaisinghani P., 3 Ways COVID-19 Has Changed Youth Activism, https://www.weforum.org/ agenda/2020/10/3-ways-covid-19-has-changed-youth-activism/ [accessed: 20.05.2021].

36 P. Jaisinghani, 3 Ways COVID-19 Has Changed Youth Activism, https://www.weforum.org/ agenda/2020/10/3-ways-covid-19-has-changed-youth-activism/ [accessed: 20.05.2021].

37 Ibidem. 
Pilotti F., Globalización y convención sobre los Derechos del Niño: el contexto del texto, Washington 2000.

Posner E., The Case against Human Rights, https://www.theguardian.com/news/2014/dec/04/-sp-case-against-human-rights [accessed: 20.05.2021].

Quijano A., Antología Esencial, Buenos Aires 2014.

Segato R.L., Antropologia e direitos humanos: alteridade e ética no movimiento de expansão dos direitos universais, "Mana" 2006, 12(1).

Shivji I.G., The Struggle for Democracy, Tanzania 2003.

UN High Commissioner for Human Rights [OHCHR], Annual Report 2020: Human Rights at the Heart of COVID-19 Response and Recovery, https://www.ohchr.org/EN/News Events/Pages/ Annual-Report-2020.aspx [accessed: 12.05.2021].

UNESCO, Educational Disruption and Response, https:/en.unesco.org/covid19/educationresponse [accessed: 14.06.2021].

UNICEF, The Impact of COVID-19 on Children's Access to Justice?, United Nations Children's Fund, Division of Data, Analytics, Planning and Monitoring, 2021.

United Nations High Commissioner for Refugees [UNHCR], Global Trends: Forced Displacement in 2019, Geneva 2020.

United Nations [UN], COVID-19 Response, 2021, https://www.un.org/en/coronavirus/un-secretary-general [accessed: 02.06.2021].

World Health Organization [WHO], Coronavirus Disease (COVID-19) Pandemic, 2020, https:// www.who.int/emergencies/diseases/novel-coronavirus-2019 [accessed: 17.06.2021]. 